\title{
ANALYSIS OF THE GOVERNMENT ROLE FOR INCLUSIVE GROWTH OF EAST JAVA PROVINCE, INDONESIA
}

\author{
Majidah Yasmin Puspa*, Master Candidate \\ Ananda Candra Fajri, Professor \\ Santoso Dwi Budi, Lecturer \\ Master's Program, Faculty of Economics and Business, University of Brawijaya, Indonesia \\ ${ }^{*}$ E-mail: yasminpuspamajidah@ymail.com
}

\begin{abstract}
The objectives of this study are to identify what kind of factors would lead the prosperity of a region and to know the role of government in resolving the income inequality in 38 districts and/or city in East Java Province, Indonesia. The research approach uses a quantitative approach with the model of treatment effect. In this method, the prosperity of a region measured through the GRDP per capita is a variable used to determine the model of treatment effect on income inequality, where 1 is for a prosperous region and 0 is for a less prosperous region. The results of this study indicate that the budget ratio has a significant effect and tends to lead to less prosperous region while the Human Development Index (HDI) has a significant effect and tends to lead to prosperous region. Variable ratio of road conditions, investment sharing, and industry sharing has no significant effect on the prosperity of a region. Furthermore, the ratio of health budget has a significant and positive effect on income inequality, while the ratio of education and infrastructure budget has no significant effect on income inequality.
\end{abstract}

\section{KEY WORDS}

Role of government, inclusive growth, prosperity, income inequality.

East Java Province is one of the provinces in Indonesia with a growth rate above the growth rate of national economic. In 2011, economic growth of East Java could rise again above the national economic growth to date after experiencing the monetary crisis of 20082009. In addition, the average per capita income (PCI) of East Java Province from 2011 to 2017 is above the national per capita income although it shows a declining trend. However, in fact the level of per capita income increase in East Java Province in recent years has not been able to reflect income distribution. Even since 2014, the ratio coefficient in the East Java Province has continued to increase until it is above the national inequality rate (BPS, 2018).

On the other hand, East Java Province has a big challenge, in which natural resources are abundant and the population is very large so that it requires more inclusive economic growth. According to Klassen (2010) Inclusive growth has two characteristics, which are reviewed through a process of growth that extends between sectors so that economic growth experiences an intensive increase in labor, causing unemployment to decline. If it is reviewed based on the results of inclusive growth which is very closely related to the pro-poor concept, the level of poverty and inequality can be reduced. Thus, inclusive growth can be defined as economic growth without discrimination against the population by equitable access to growth and it can reduce inter-group disparities.

The role of government plays an important role in creating inclusive growth. In a country, the role of government can be done through fiscal policy, namely the State Budget and Revenue. Since the implementation of regional autonomy, each region has full authority in regulating the financial of the Regional Revenue and Expenditure Budget while continuing to comply with applicable laws and regulations. Based on data from the Directorate General of Fiscal Balance (2018), in general the budget issued by the government in each sector fluctuates every year according to the needs of each region. 


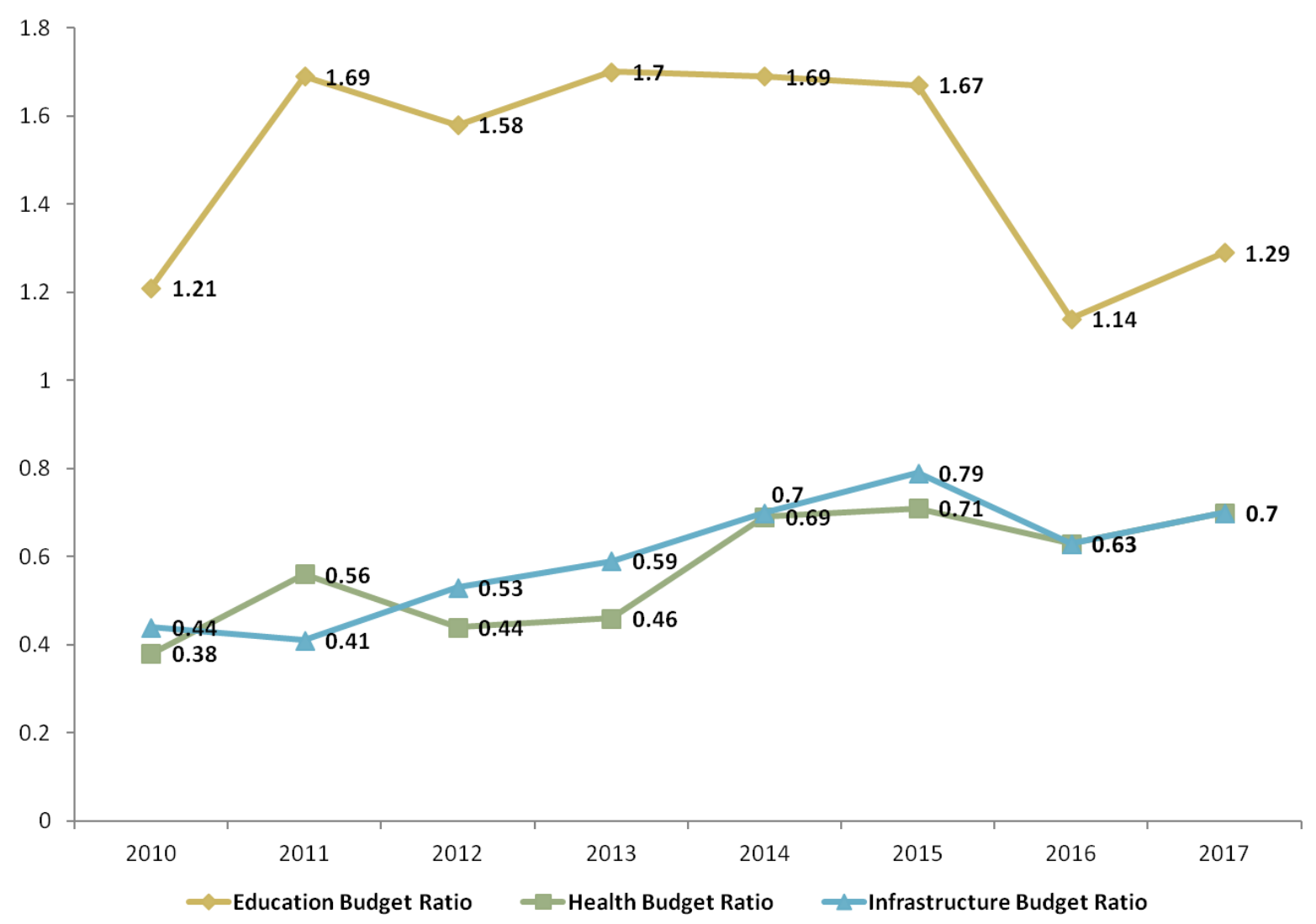

Figure 1 - Ratio of Education Budget, Infrastructure Budget, Health Budget (Source: Directorate General of Fiscal Balance, 2018, data processed)

When viewed from Figure 1, the trend of ratio of education budget shows a downward trend while the health and infrastructure budget shows an upward trend. According to I Gusti Putri Ayu et al (2014) stated that government expenditure has a significant and positive effect on income inequality. Whereas research by Heri Suparno (2014) and Diah et al (2017) explains that there is a negative and significant effect between infrastructure budgets and income inequality, while there is no significant effect between education and health budgets on income inequality. Thus, there are some problems that need to be fixed considering the role of government is needed in reducing income inequality. Therefore, further research is needed on the government expenditure budget on income inequality.

The focus of this study is to know how the role of government to reduce the income inequality so that it develops the inclusive growth. The objective of this study is to know what factors can influence the prosperity of a region and to determine the effect of prosperity and the role of government by education budget, infrastructure budget and health budget on income inequality.

\section{LITERATURE REVIEW}

According to Todaro (2006), fairness of income equality in developing countries is a condition that supports economic growth. So the high level of income inequality in a region will greatly impact negatively on the achievement of economic growth. However, economic growth that varies in intensity will cause economic inequality and income inequality in each region (Sirojuzilam, 2008). Income inequality in the central region is a natural thing, this happens because of differences in resources and time of implementation of development between each region (Williamson, 1965). Todaro (2006) explains the level of income inequality can be measured through the Gini coefficient (Gini Ratio). 
In 1995, Simon Kuznet put forward an analysis linking the stages of economic development, income distribution and growth compared to equity (Todaro, 2006). In his theory, Kuznet argues that the U-shaped pattern requires that in the first stage of development (represented by low GDP per capita), the growth process is followed by a worsening income distribution and after reaching a certain point, the development will be followed by improved equity.

Syafrizal (2008) explains that there are several factors that influence the income inequality, namely differences in the content of natural resources, differences in geographical conditions, concentration of economic activity in certain regions and differences in the allocation of development funds. Some factors that cause inequality in income distribution from the viewpoint of economists, according to Thee Kian Wee (1981) are classified into three parts, namely, firstly, income distribution inequality between income distribution groups (second, size distribution income), secondly, income development disparity between urban and rural areas (urban-rural income disparities) and thirdly, regional income disparity (regional income disparities).

UNDP (United Nations Development Programme) defines inclusive growth based on income and production, namely the process and results of growth in which all parties can participate and get the same benefits from the results of that growth (UNDP, 2008). An important requirement for creating inclusive growth is that income disparities between workers in the agricultural and non-agricultural sectors should not be too large (Sen, 2007). Thus, inclusive economic growth reflects the equitable distribution of income between individuals or even between groups.

National income defined as the total of consumption, investment, government expenditure, and net export expenditure (Dumairy, 1999). While the prosperity of the population in an area is not only in terms of the rate of economic growth but also it can be demonstrated through per capita income in the region (Iskandar A, 2014). Keynesian growth theory explains how the government can affect the macro economy to achieve full employment (Tarigan, 2005).

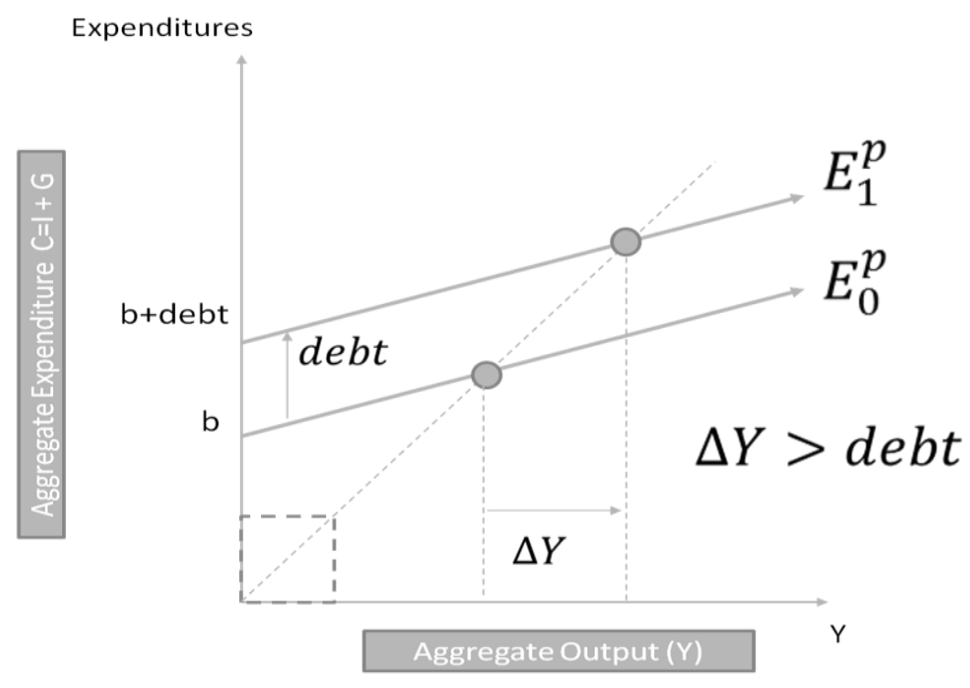

Figure 2 - Adaptation of the theory of government expenditure based on Keynes's theory (Sources: Adapted from Elemendorf and Mankiw, 1998)

In Keynes's theory, there is the term of government multiplier where government spending can have a multiplier effect as shown in Figure 2. Initially, government spending in the economy is at point $Y$ until the government has a plan to advance economic growth by increasing government spending (for example by debt). Furthermore, this increase in government expenditure has a multiplier effect so that with greater government expenditure the resulting output is much greater ( $\mathrm{Y}$ shifts to right). 


\section{METHODS OF RESEARCH}

This study is a quantitative research using secondary data with the research location of 38 regencies / cities in East Java from 2010-2017. Data sources were obtained from the official website of the Directorate General of Fiscal Balance and the Central Statistics Agency. In this research, the research method used is the treatment effect model.

This method reviews the effect of the average of binary variables on the variables subject to treatment (outcome variables) (Heckman and Robb, 1986). In this case, there are several variables that are considered to be having some treatment (untreated) and some will not have any treatment (untreated). This method can estimate the sample by comparing the average value for the unit receiving treatment or not.

The prosperity variable $\left(D_{i t}\right)$ in the first equation is a binary variable where 1 for prosperous regions, ie regions that have per capita income above the average per capita income of East Java Province, while 0 for regions that have per capita income below the average per capita income of East Java Province. In the first equation, the prosperity variable $\left(D_{i t}\right)$ is influenced by many factors, namely the budget ratio $\left(X_{1 i t}\right)$, the ratio of roads condition $\left(X_{2 i t}\right)$, investment sharing $\left(X_{3 i t}\right)$, HDI (Human Development Index) $\left(X_{3 i t}\right)$, and industry sharing $\left(X_{5 i t}\right)$. For the second equation, income inequality variable $Y_{i t}$ is influenced by many factors, namely prosperity $\left(D_{i t}\right)$, education budget ratio $\left(X_{6 i t}\right)$,, health budget ratio $\left(X_{7 i t}\right)$,, infrastructure budget ratio $\left(X_{8 i t}\right)$ and year in dummy variable $\left(C_{i t}\right)$.

\section{RESULTS AND DISCUSSION}

This study uses quantitative descriptive methods and treatment effect models. In this model, we will find the effect of the average binary variable $(0 / 1)$ on the treated variable (Heckman and Robb, 1986). Based on the results of data processing using the treatment effect model, the following output is obtained.

Table 1 - Estimated Results from Treatment Effect Model

\begin{tabular}{|c|c|c|c|c|}
\hline Variable & Coefficient & Std. Error & $\mathrm{z}$ & $P>[z]$ \\
\hline \multicolumn{5}{|l|}{ [1] Prosperity } \\
\hline Budget Ratio & $-3.36 \mathrm{E}-05$ & 0.000017 & -1.98 & $0.048^{*}$ \\
\hline Ratio of roads condition & -0.010021 & 0.011468 & -0.87 & 0.382 \\
\hline Investment Sharing & -0.042912 & 0.596401 & -0.72 & 0.472 \\
\hline HDI Human Development Index & 0.2807042 & 0.098318 & 2.86 & $0.004^{* *}$ \\
\hline Industry Sharing & 0.0235054 & 0.024521 & 0.96 & 0.338 \\
\hline Constanta & -16.16983 & 5.795495 & -2.79 & 0.005 \\
\hline \multicolumn{5}{|l|}{ [2] Income Inequality } \\
\hline Ratio of Education Budget & -0.028799 & 0.044098 & -0.65 & 0.514 \\
\hline Ratio of Health Budget & 0.2150392 & 0.097437 & 2.21 & $0.027^{*}$ \\
\hline Ratio of Infrastructure Budget & -0.09754 & 0.090935 & -1.07 & 0.283 \\
\hline Year & 0.0158374 & 0.011037 & 1.44 & 0.151 \\
\hline Prosperity & 0.0263327 & 0.010094 & 2.61 & $0.009^{* *}$ \\
\hline Constanta & 0.3036812 & 0.027406 & 11.08 & 0 \\
\hline Prob $>$ Chi2 (F) & \multicolumn{4}{|l|}{0.0001} \\
\hline Prob $>$ Chi2 (R-Square) & \multirow{2}{*}{\multicolumn{4}{|c|}{0.1197}} \\
\hline$(* *)$ Significance at $1 \%$ & & & & \\
\hline \multicolumn{5}{|l|}{$(*)$ Significance at $5 \%$} \\
\hline
\end{tabular}

Based on table 1, the probability of the Chi-Square test is 0.0001 (below the error level of $5 \%$ or 0.05 ). Thus, this equation is valid in explaining income inequality that is affected by the prosperity of a region. The equations can be written as follow:

$$
\begin{gathered}
D_{1 i t}=-16.169-0.0000336 X_{1 i t}-0.01002 X_{2 i t}-0.0429 X_{3 i t}+0.28070 X_{4 i t}+0.02350 X_{5 i t}+\varepsilon_{i t} \\
Y_{i t}=0.3036+0.0263 D_{i t}-0.02879 X_{6 i t}+0.2150 X_{7 i t}+-0.0975 X_{8 i t}+0.0158 C_{i t}+\varepsilon_{i t}
\end{gathered}
$$


The first equation is the factors that affect the prosperity of an area with $5 \%$ error tolerance. It was obtained that the ratio of the government budget had a significant and negative effect on regional prosperity in East Java Province. Partially, it is explained that the higher the budget spent by the government to encourage economic growth, the region will tend to become less prosperous regions. This is because there are many regions that need a bigger budget to boost their economy.

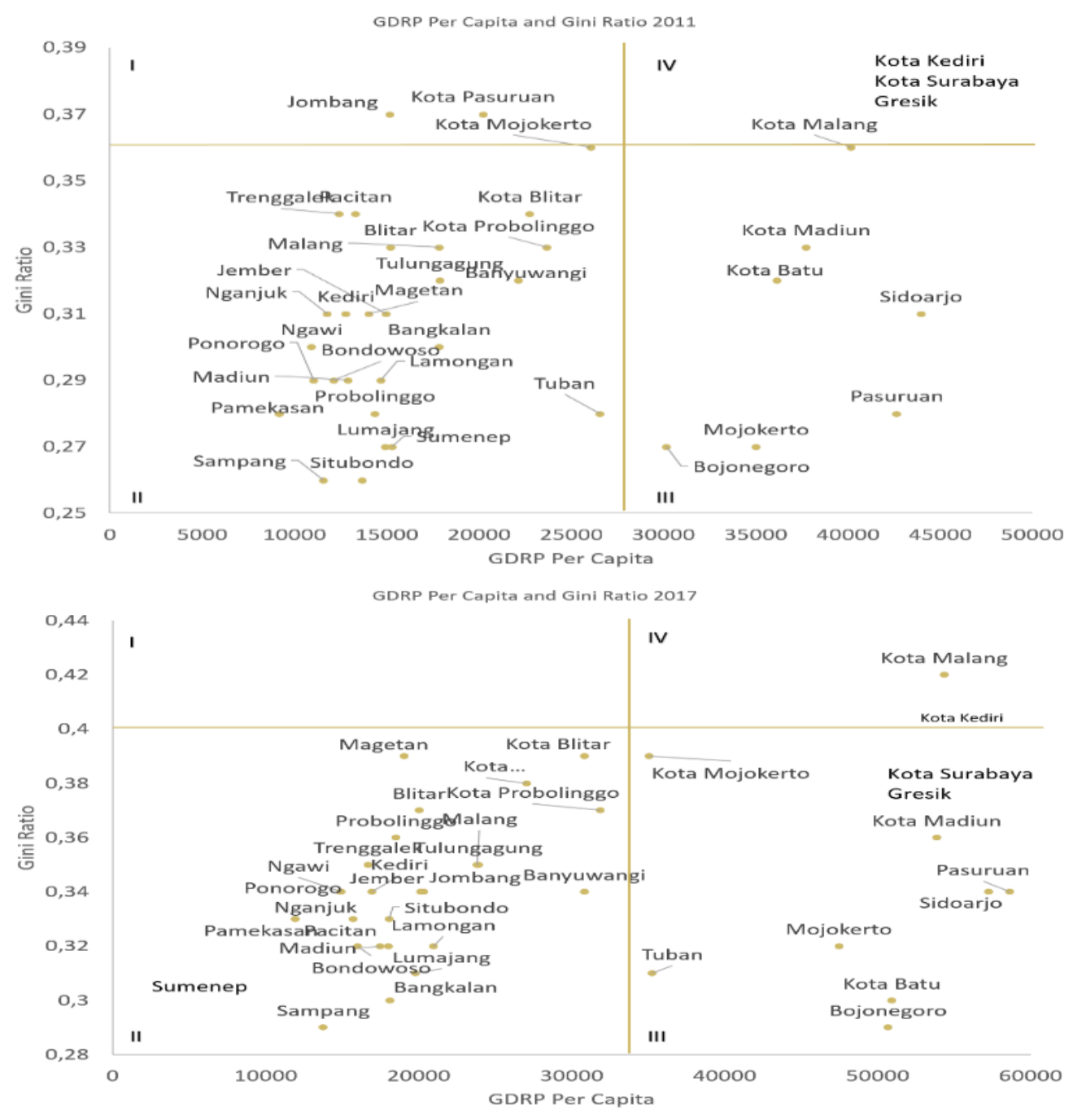

Figure 3 - GDRP Per Capita and Gini Ratio East Java Province in 2011 and 2017 (Source: Central Bureau of Statistics Indonesia, 2018, data processed)

In figure 3 , it can be seen that in 2011 , less prosperous regions (left) were more numerous than prosperous regions (right). That is, the majority of government spending is allocated in less prosperous areas. Basically, this is a positive side where the government provides more budget for less prosperous regions, the goal is to accelerate economic growth. This result is in line with research by I Gusti Ayu Putri Wahyuni et al (2014).

In addition, in the first equation it is known that HDI (Human Development Index) has a significant and positive influence on regional prosperity in East Java Province. In this case, the quality of human resources (HDI) will tend to increase prosperity because increasing human resource capabilities in managing natural resources, capital and technological mastery will accelerate economic growth. This condition can be seen from school expectations and the human development index which has been on an upward trend since 2011 (BPS, 2018). This is in line with research by Irham Iskandar (2017) and Diah Pradnyadewi et al (2017). 


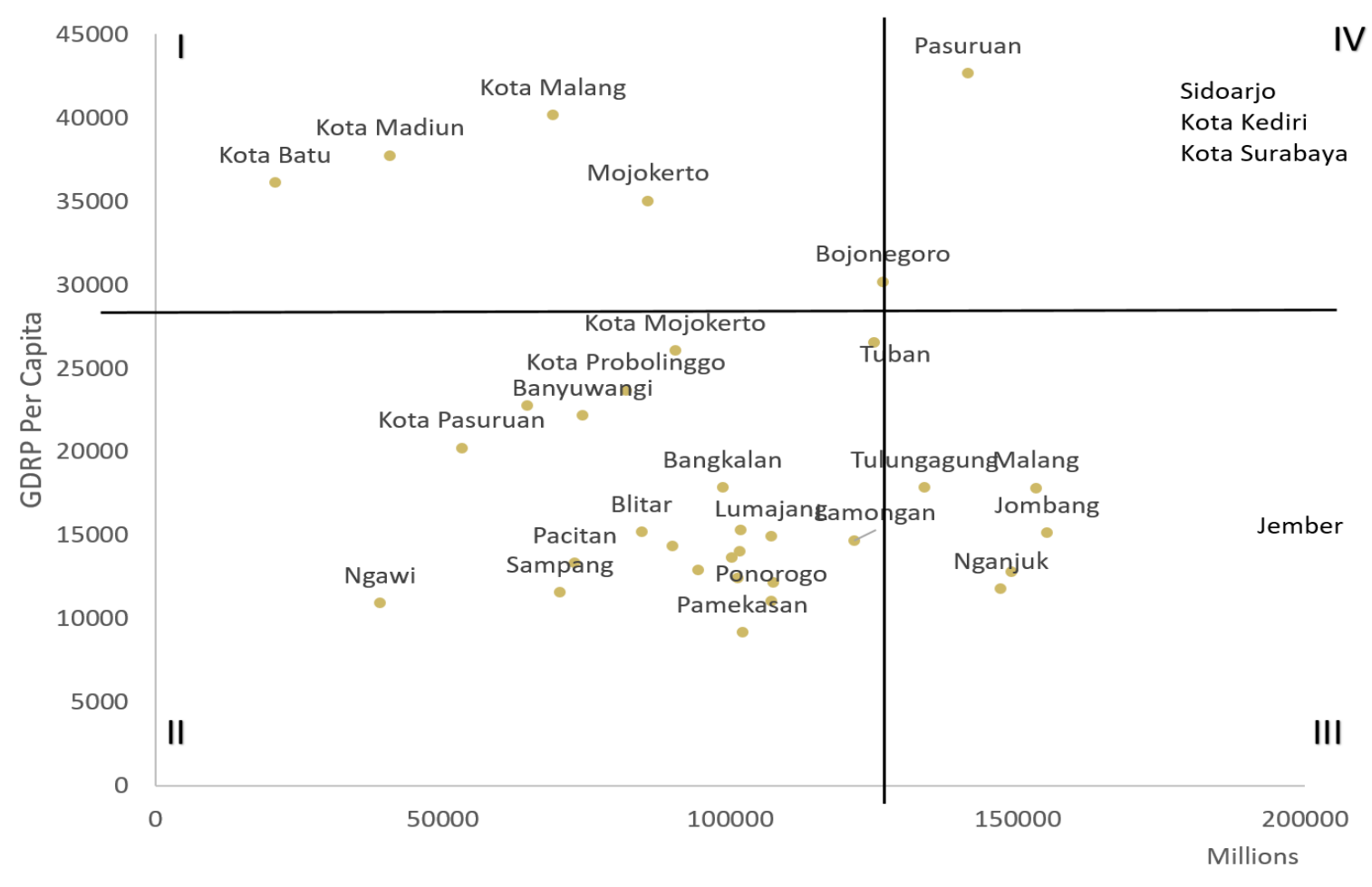

Health Budget 2011

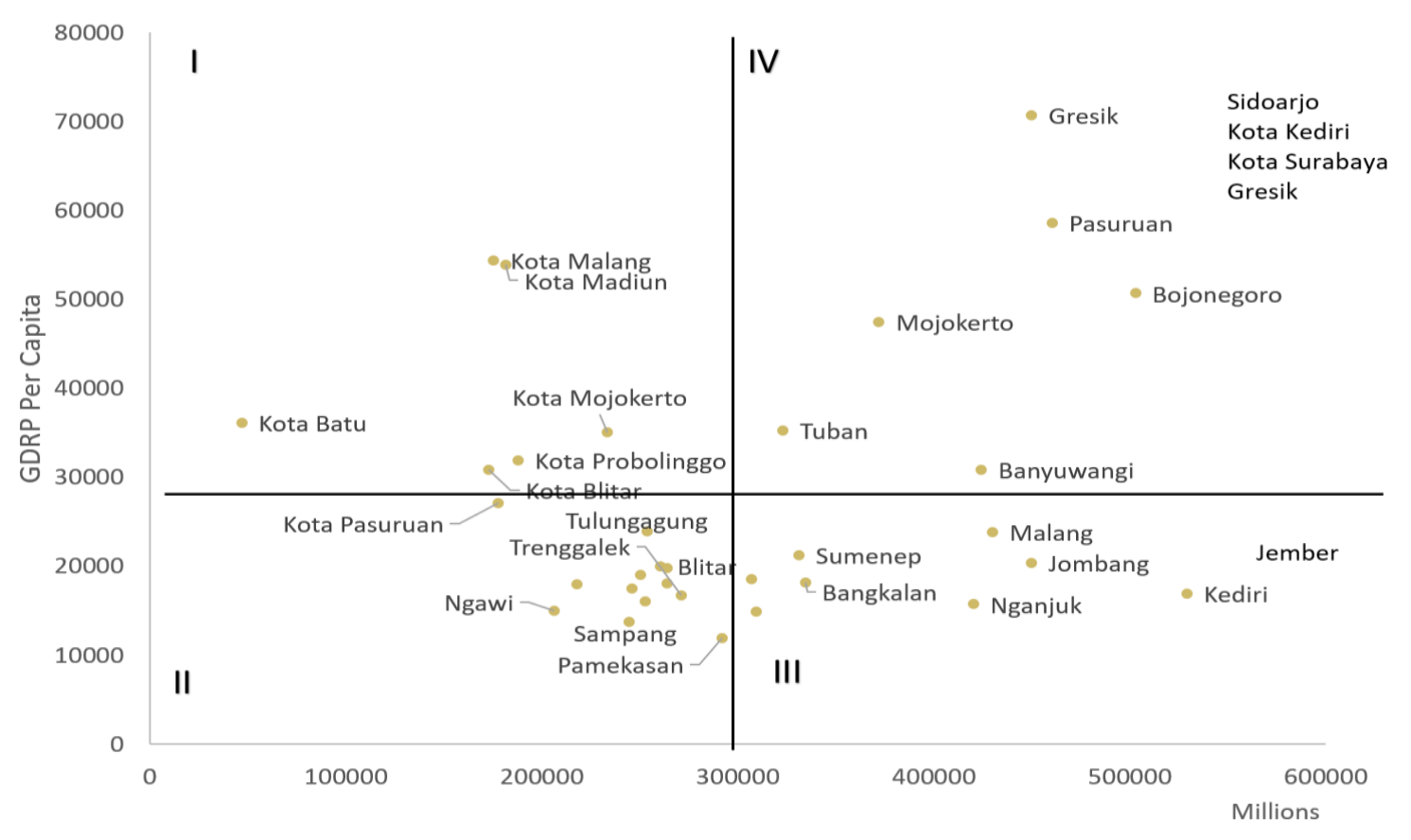

Health Budget 2017

Figure 4 - Health Budget in the Prosperous and Less Prosperous Regions in East Java Province in 2011 and 2017 (Source: Directorate General of Fiscal Balance, 2018, data processed)

On the other hand, the ratio of road condition has no significant effect because most of those who make benefit of this road in good condition infrastructure are from the rich compared to the poor. Investment sharing has no significant effect because most of the contributors to regional investment (PMTB) are people from the middle to upper class. Sharing industry does not have a significant effect on prosperity because there is a industry in sharing areas in the province of East Java and also uses more workers from the province of East Java so that it does not have a significant impact on people's income. 
In the second equation, the health budget ratio has a positive and significant effect on income inequality in districts / cities in East Java Province. Every increase of ratio of health budget of $1 \%$ then inequality in East Java Province will increase by 0.215039 . It can also be seen that prosperous regions will tend to increase income inequality in East Java Province by 0.0263327 . It can also be seen that prosperous regions will tend to increase the level of income inequality in East Java Province by 0.0263327 . The income inequality of regencies / cities in East Java Province in 2011 and 2017 did not experience a significant difference. Furthermore, ratio of education and infrastructure budget does not significantly influence income inequality in East Java Province. This is because the growth of the health budget is greater in the already prosperous regions as shown in Figure 3.

In figure 4, it can be seen that the growth of the health budget with a large amount is faster in the prosperous region (quadrant 2), ie previously in 2011 there were 6 regions while in 2017 there were 7 regions with a health budget three times bigger than in 2011. This of course will encourage income inequality where there should be less affluent regions that have higher health budgets, especially non-affluent regions with lower health budgets in 2011 more than in 2017. This condition is also due to these regions having a high level of income inequality so that it will tend to exacerbate income inequality in the region. This result is not in line with research by Heri Suparno (2014) which suggests that the health budget has a positive and not significant effect on income inequality.

Ratio of education budget has no significant effect because the budget is more directed towards the school itself than access to education by the poor. This is indicated by the level of school participation rates in East Java Province tending to decrease (BPS, 2018). Furthermore, the infrastructure budget ratio does not have a significant effect because access to the results of development by the government in the infrastructure sector has greater benefits for people with middle and upper economies.

\section{CONCLUSION}

The budget ratio has a significant and negative sign on the prosperity of the Regencies / Cities because most government spending is mostly in less prosperous regions. HDI (Human Development Index) has a significant and positive sign on the prosperity of the Regency / City due a higher HDI tends to lead to prosperous Regencies / Cities. Ratio of Health Budget has a positive and significant effect on income inequality in East Java Province because the growth of the health budget is greater in prosperous regions.

\section{REFERENCES}

1. Arsyad, Lincolin. 2010. Ekonomi Pembangunan. Yogyakarta: Unit Peberbit and Percetakan STIM YKPN Yogyakarta.

2. Badan Pusat Statistik. 2018. Tabel Gini Rasio Menurut Kabupaten/Kota di Jawa Timur 2008-Maret 2018. jatim.bps.go.id/dynamictable/2018/10/18/410/gini-rasio-menurutkabupaten-kota-di-jawa-timur-2008---maret-2018.html.

3. Badan Pusat Statistik. 2018. Tabel Gini Rasio Provinsi 2002-2018. www.bps.go.id/dynamictable/2017/04/26/1116/gini-ratio-provinsi-2002-2018.html.

4. Badan Pusat Statistik. 2018. Angka Harapan Sekolah (AHS) Penduduk Jawa Timur Menurut Kabupaten Kota (IPM Metode Baru), 2010-2017. jatim.bps.go.id/dynamictable/2018/04/16/399/angka-harapan-sekolah-ahs-pendudukjawa-timur-menurut-kabupaten-kota-ipm-metode-baru-2010-2017.html.

5. Badan Pusat Statistik. 2018. Angka Partisipasi Kasar (APK) Menurut Kabupaten/Kota and Kelompok Usia Sekolah di Jawa Timur. https://jatim.bps.go.id/subject/28/pendidikan.html\#subjekViewTab3.

6. Diah, dkk. 2017. Pengaruh IPM, Biaya Infrastruktur, Investasi and Pertumbuhan Ekonomi Terhadap Ketimpangan Distribusi Pendapatan di Provinsi Bali. E-Jurnal Ekonomi Pembangunan Universitas Udayana Vol. 6 No. 2.

7. Dumairy. 1999. Perekonomian Indoinesia. Erlangga. Jakarta. 
8. Efriza, Ulfie. 2014. Analisis Kesenjangan Pendapatan Antar Kabupaten/Kota Di Provinsi Jawa Timur Di Era Desentralisasi Fiskal. Malang: Universitas Brawijaya.

9. Eko Wicaksono, dkk. February 2017. The Sources Of Income Inequality In Indonesia: A Regression-Based Inequality Decomposition. Asian Development Bank Institute Working Paper Series No. 667.

10. Eunike dkk. 2015 Pengaruh Investasi Pemerintah and Tenaga Kerja Terhadap Pertumbuhan Ekonomi di Kota Manado (Studi Pada Kota Manado Tahun 2003-2012). Jurnal Berkala Ilmiah Efisiensi Vol. 15 No. 4.

11. Ferry and Spero. 2017. Analisis Kausalitas Pengeluaran Pendidikan and Pertumbuhan Ekonomi di Indonesia. Periode 1971-2004. Universitas Andalas: Fakultas Ekonomi.

12. Ferreira, F. and J. Gignoux. 2008. The measurement of inequality of opportunity. World Bank Policy Research Working Paper 4659. Washington DC: The World Bank.

13. Friawan, D. (2008). Kondisi Pembangunan Infrastruktur di Indonesia. CSIS Vol.37. No.2 Juni 2008, Jakarta: Lembaga Penerbit Fakultas Ekonomi Universitas Indonesia

14. Heckman, J. J., and Robb, R. (1986). Alternative Methods for Solving the Problem of Selection Bias in Evaluating the Impact of Treatments on Outcomes. New York.

15. Mahardiki, Doni and Rokhedi. 2013. Analisis Perubahan Ketimpangan Pendapatan and Pertumbuhan Ekonomi Antar Propinsi di Indonesia 2006-2011. Journal of Economics and Policy 6: 103-213.

16. M. H. Suryanarayana. 2013. Inclusive Growth: A Sustainable Perspective. United Nation Development Programme. UNDP: India.

17. Nurul, Ribut and Anugerah Karta. 2016. Pengaruh Pendidikan Terhadap Ketimpangan Pendapatan Tenaga Kerja di Indonesia. Jurnal Kependudukan Indonesia Vol. 11 No. 1.

18. Panca, Erni. 2013. Ketimpangan Wilayah di Provinsi Kalimantan Barat Suatu Kajian terhadap Hipotesis Kuznet. Jurnal Eksos Vol. 9 No. 1 HIm 36-48 ISSN 1693-9093.

19. Klasen, Stephan. June 2010. Measuring and Monitoring Inclusive Growth: Multiple Definitions, Open Questions, and Some Constructive Proposals. Asian Development Bank Sustainable Development Working Paper Series. No. WPS102016 ISSN 20719450.

20. Sirojuzilam, 2008. Disparitas Ekonomi and Perencanaan Regional, Pustaka Bangsa Press, Medan.

21. Sen, Kunal. 2014. Inclusive Growth: When May We Expect It? When We May We Not? Asian Development Review Vol. 31, No. 1 pp. 136-162. Asian Development Bank and Asian Development Bank Institute.

22. Sjafrizal. 2008. Ekonomi Regional: Teori and Aplikasi. Padang: Baduose Media.

23. Sukirno, Sadono. 1985. Ekonomi Pembangunan: Proses, Masalah and Dasar Kebijaksanaan. Jakarta: FEUI.

24. Suparno, Heri. 2014. Pengaruh Pengeluaran Pemerintah Sektor Pendidikan, Kesehatan, and Infrastruktur Terhasap Pertumbuhan Ekonomi and Peningkatan Pembangunan Manusia di provinsi Kalimantan Timur. Ekonomika-Bisnis Vol. 5 No. 1 hal 1-22.

25. Suryanto, Dwi. 2011. Analisis Pengaruh Tenaga Kerja, Tingkat Pendidikan, and Pengeluaran Pemerintah Terhadap pertumbuhan ekonomi di Subosukawonosatren Tahun 2004-2008. Semarang: Skripsi Fakultas Ekonomi Universitas Diponegoro.

26. Tarigan, Robinson. 2005. Ekonomi Regional. Medan: Bumi Aksara.

27. Thee Kian Wee. 1982. Perekonomian di Negara Berkembang. Jakarta-Pustaka Jaya.

28. Todaro M. P. 2006. Pembangunan Ekonomi Dunia Ke Tiga. Edisi Kesembilan. Jakarta: Erlangga. 